\title{
一般口演10
}

\section{精神的ストレスが㐘根膜感覚，煩部皮膚触覚に及ぼす 影響に関する検討}

A study of the effect of mental arithmetic stress on periodontal sensation and tactile sensation on cheek

\author{
○宋本儒享, 沖 和広, 加藤聖也, 皆木省吾 \\ Michitaka Somoto, Kazuhiro Oki, Seiya Kato, Shogo Minagi \\ 岡山大学大学院医歯薬学総合研究科咬合・有床義歯補綴学分野 \\ Department of Occlusal and Oral Functional Rehabilitation, Graduate School of Medicine, \\ Dentistry and Pharmaceutical Sciences, Okayama University
}

\section{I. 目的}

歯科外来患者の中には, 咬合感覚異常を訴える者がみ られることがある。歯根膜感覚が三叉神経由来の体性感 覚であることを勘案すると，『歯根膜感覚を含めた顎口 腔領域の知覚は, 精神的ストレスによって变化する』と いう仮説を検証することによって, 現状では対応に難渋 する咬合感覚異常を対象とした咬合治療の診断・治療の 一助となり得ると考えられる。

本研究では，暗算負荷による精神的ストレスが，咬合 感覚に特異的に影響を及ぼすかどうかを検討するため に, 三叉神経第 2 枝の支配を受ける歯根膜感覚絶対閾值 および㚘部皮膚触覚の弁別閾值が暗算負荷前後において どのように変化するかについて検討を加えることを目的 とした。

\section{II. 方法}

本研究プロトコールのアウトラインを図 1 に示す.

被験者は 20 代の健常成人とし, 計測対象歯である上 顎左側第一大臼歯が生活歯であり対合歯が存在するもの とした.これらの診査は, 全顎的歯周精密検査と岡山大 学病院咬合・義歯補綴科外来で使用している顎関節症診 査プロトコールによって行った. 術前診査から, 歯根膜 感覚絶対閾值計測は 20 名（男性 10 名, 女性 10 名), 㚘 部皮膚触覚弁別閾值計測は 13 名（男性 8 名，女性 5 名） を対象とした。

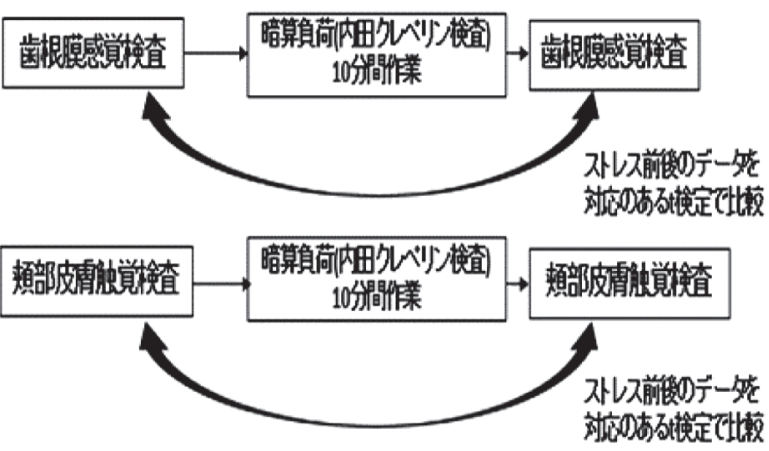

図 1 研究のアウトライン

《歯根膜感覚絶対閾值計測》

本研究では，歯面に対して歯軸方向から加えられた撃 力に対する自覚最小強度を歯根膜感覚絶対閾值と定義 し，階段法によって絶対閾值を計測した。計測装置は Morimoto $ら^{1)}$ が考案, 作製した刺激装置に, 平田ら ${ }^{2)}$ が 装置設置方法と撃力発生機構に改良を加えたものとした.

《㚘部皮膚触覚弁別閾值計測》

煩部皮膚触覚の弁別閾值計測には，知覚検査用モノ フィラメント (TOUCH TEST $\left.{ }^{\circledR}\right)$ を用いた。モノフィ ラメントの操作は，モノフィラメントを検査部位に 1 1.5秒かけて垂直に降ろし，1～1.5秒かけてモノフィラ メントがたわむまでモノフィラメントを押しつけ, 1.5 秒かけて元の位置に戻すようにして行った．弁別閾值計 測は極限法によって行った。 


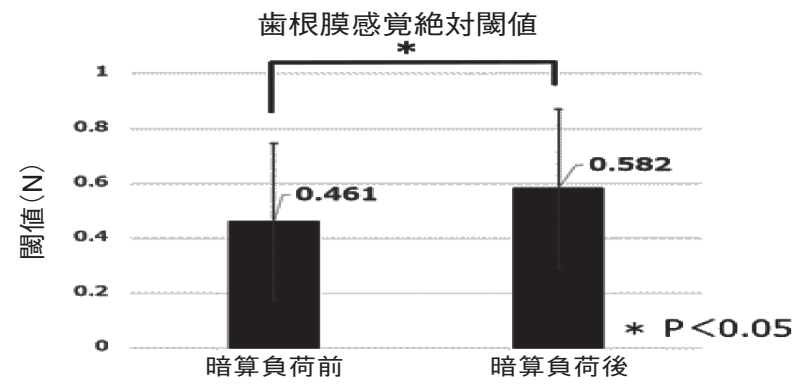

図 2 暗算負荷前後の歯根膜感覚絶対閾値

\section{《心理的ストレスの評価》}

感覚閾值検査の前（1 回目）と暗算負荷後（2 回目） に，携帯型血圧計を用いて，心拍数と血圧を観察し，研 究参加者の安静状態およびストレス曝露状態を客観的に 評価した。

《暗算負荷による精神的ストレス》

内田クレペリン検査 ${ }^{\circledR}$ 専用回答用紙を用いて，10分間 の連続加算作業を行わせた。

\section{《統計解析》}

等分散性について確認後，対応のある $\mathrm{t}$ 検定を行った (両側検定， $\alpha=0.05$ ).

\section{III. 結果及び考察}

《暗算負荷前後の歯根膜感覚閾値の比較》

歯根膜感覚閾值は，暗算負荷後に統計学的に有意に増 加し $(\mathrm{p}=0.012)$, 安静時に比べて約 1.3 倍の閾值が観察 された。

\section{《暗算負荷前後の煩部皮膚触覚閾值の比較》}

触覚弁別閾值は増加しているものの, 統計学的有意差 はみられなかった $(\mathrm{p}=0.467)$.

\section{《暗算負荷前後の循環器系指標の比較》}

収縮期血圧（ $p=0.001 ） ，$ 拡張期血圧 $(p=0.008)$, 心拍数 $(\mathrm{p}=0.041)$ のいずれにおいても有意差を認めた。

本研究の結果から，暗算負荷による精神的ストレス は, 歯根膜感覚絶対閯值を増加させる可能性が示唆され た。一方，煩部皮膚触覚の弁別閾值には，統計学的有意 差はみられなかった。この原因としては，使用した知覚

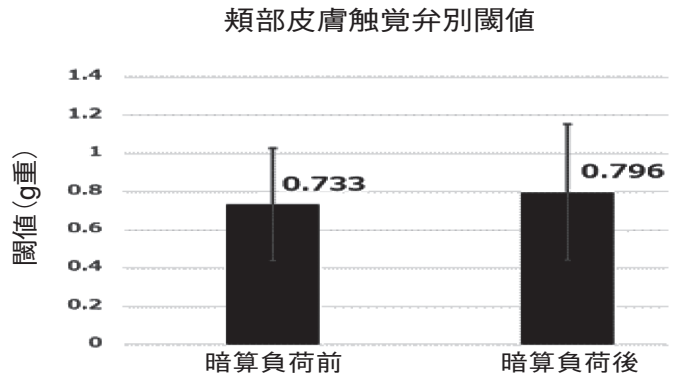

図 3 暗算負荷前後の煩部皮膚触覚弁別闇値

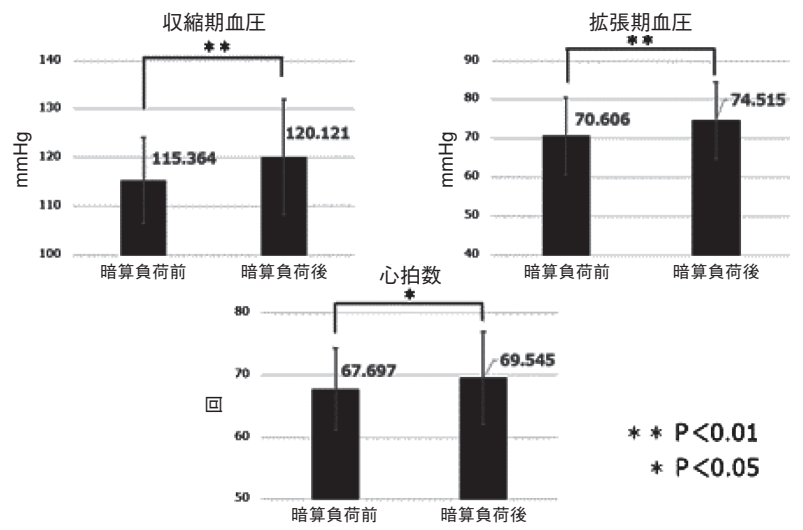

図 4 暗算負荷前後の循環器系指標

テスターの刺激間強度が精神的ストレスによる弁別閾值 の変化を詳細に検出できなかった可能性と，速順応性機 械受容器によって知覚される皮膚触覚は，遅順応性受容 器による歯根膜感覚とは精神的ストレスに対する反応が 異なる可能性が考えられる。これら原因については今後 詳細に検討を加える必要があると思われる。

\section{N. 文献}

1) Yuta Morimoto, Kazuhiro Oki, Sachiyo Iida, Chieko Shirahige, Naoto Maeda, Shigehisa Kawakami, Tadashi Matsunaga, Shogo Minagi. Effect of transient occlusal loading on the threshold of tooth tactile sensation perception for tapping like the impulsive stimulation. Odontology 2013; 101: 199-203.

2 ) 平田敦俊. 筋・筋膜痛患者の歯根膜感覚閾値と咬 筋筋活動時間についての研究. 岡山歯学会雑誌 35(1) : 2016 